\title{
E3 Ubiquitin-Protein Ligase MARCH9
}

National Cancer Institute

\section{Source}

National Cancer Institute. E3 Ubiquitin-Protein Ligase MARCH9. NCI Thesaurus. Code

C113308.

E3 ubiquitin-protein ligase MARCH9 (346 aa, $\sim 38 \mathrm{kDa}$ ) is encoded by the human MARCH9 gene. This protein is involved in the ubiquitination of plasma membrane proteins. 